\title{
Degradation of paint films. IV.
}

UDC

$667.621 .424^{\prime} 13.75$

$: 620.191 .7$

668. $473.09: 665.333 .5 .09$

\section{Degradation of the films of urethane oil prepared from tall oil fatty acid and rice oil fatty acid}

\author{
Takeshita Toshio, Mryauchi Noriyuki, \\ HARAguchi Reiko and NAgai Takanori \\ The Faculty of Engineering, Kagoshima University*
}

\begin{abstract}
The authors carried out out door degradation test of the films of some urethane oils. The urethane oil was synthesized by the reaction of TDI (Tolylene-di-isocyanate) with partial fatty acid ester of pentaerythritol. Authors synthesized the tall penta $3: 1$ urethane oil as follows : One mol of distillated grade tall oil fatty acid was reacted with $1 / 3 \mathrm{~mol}$ of pentaerythritol at $200^{\circ} \mathrm{C}$ for 2 hours and at $230^{\circ} \mathrm{C}$ for 4 hours. Then the product was reacted with stoichiometrical TDI in the presence of $\mathrm{Pb} 0.4 \%$ and $\mathrm{Co} 0.05 \%$ catalyst at $60^{\circ} \mathrm{C}$ for $30 \mathrm{~min}$, at $70^{\circ} \mathrm{C}$ for $30 \mathrm{~min}$ and at $80^{\circ} \mathrm{C}$ for $30 \mathrm{~min}$.

Tall penta $2: 1$ urethane oil, alkali isomerized tall penta $3: 1$ urethane oil and rice penta $2: 1$ urethane cil were also synthesized.

Changes of IR spectra of the films of these urethane oils were measured as follows : Sample was coated on a polyethylene $20 \mu$ film at the thickness of about $25 \mu$. The coated film was fixed on a frame of polyvinyl chloride resin, then IR spectrum was measured by a double beam type IR spectrophotometer, putting another not coated polyethylen film in the position of compensate cell. Then the coated film was exposed for 10 months, and the spectrum was measured at intervals.

Changes of weights, hardness and gloss were measured of the films coated on a glass plate, and flexibility was also measured on the films coated on a tin plate.

Discussion : Nonexposed tall penta 3:1 urethane oil film had absorption peak at $3300 \mathrm{~cm}^{-}(\mathrm{OH}$ and $\mathrm{NH})$, $2926 \mathrm{~cm}^{-}\left(\mathrm{CH}_{2}\right), 1725 \mathrm{~cm}^{-}$(urethane carbonyl and ester carbonyl), $1600 \mathrm{~cm}^{-}$(benzene ring), $1525 \mathrm{~cm}^{-}$(amide III), $1230 \mathrm{~cm}^{-}$(amide III +ester), $1175 \mathrm{~cm}^{-}$(ester C-O-C), $1065 \mathrm{~cm}^{-}$(carbamate C-O-C), $1035 \mathrm{~cm}^{-}$(pentaerythritol skeletal), $815 \mathrm{~cm}^{-}\left(1,2,4\right.$ trisubstituted benzen $\mathrm{C}-\mathrm{H}$ out of plane) and $770 \mathrm{~cm}^{-}(1,2,3$ trisubstituted benzen $\mathrm{C}-\mathrm{H}$ out of plane) and $730 \mathrm{~cm}^{-}\left(\mathrm{CH}_{2}\right.$ rocking). Optical density changes of these absorption on exposing were plotted to the lapse of month. Decreasing speeds of $1725 \mathrm{~cm}^{-}, 1525 \mathrm{~cm}^{-}$, and $1230 \mathrm{~cm}^{-}$were almost equal to the decreasing speed of the weight of glass plate film. Therefore it must be said that urethane part of the film was unchanged on exposing. Optical density of $3300 \mathrm{~cm}^{-}, 1050 \mathrm{~cm}^{-}, 1175 \mathrm{~cm}^{-}$ decreased more slowly than the weight, which seems that $\mathrm{OH}$ and ester group increased on exposing. That of $2926 \mathrm{~cm}^{-}$decreased much more rapidly than the weight loss, which seems that $\mathrm{CH}_{2}$ part diminished quickly on exposing.

Tests of tall penta $2: 1$ urethane oil, alkali-isomerized tall penta $3: 1$ urethane oil and rice penta $2: 1$ urethane oil gave same results.

Gloss of each oil films was lost down to about $60 \%$ after 1 month exposing and was unchanged after that time. Hardness (Sword hardness) of comparatively soft film increased to about 20 gradually. But the films lost flexibility inversely after exposing.
\end{abstract}

* 52 kamoikecho Kagoshima-shi, Japan. 


\title{
報文
}

\section{塗膜の劣化に関する研究 $(\text { 第 } 4 \text { 報 })^{*}$}

トール油脂肪酸, *ヌカ油脂肪酸ウレタン化油塗膜の劣化
UDC

$667.621 .424^{\prime} 13.75$

$: 620.191 .7$

668. $473.09: 665.333 .5 .09$

\section{竹下寿雄**. 宮内德之林。原口玲子***. 永井隆德****}

\author{
要旨
}

トール油, 米ヌカ油, アルカリ異性化トール油各脂肪酸と, ペンタエリトリットを $3: 1$ お よび $2: 1$ モル比で反応させてセミエステルを作り, これと当量のトリレンジイソシアネート （TDI）を反応させてウレタン化油を作り，これらをポリエチレンフィルムに塗装した塗膜 を屋外に暴露して，未塗装ポリエチレンを補償光路に入れることにより，塗膜のみの暴露によ る赤外スペクトル変化を追及した。一方ガラス板に塗装した塗膜の物性変化子測定した。その 結果, トール油脂肪酸とペンタエリトリット 3 対 1 モル比反応物から作ったウレタン化油が一 番耐候性よく, 劣化の機構としては, ウレタン結合には変化が現われず, 水酸基, エステル基, エポキシ基の増加，メチレン基の減少が観察された。メチレン部がこのように酸化されて劣化 して行くものと推定した。

\section{1. 緒言}

著者らは前報1)で, アマニ油物よび重合シナキリ油塗 㷬（クリヤ）の屋外暴露の際の劣化を, 赤外線吸収スペ クトルの変化と塗膜物性変化から研究し, これらの乾性 油塗膜は顔料を含まない場合はきわ方急速に劣化し， 1 ミルのブレードで塗装した塗膜は，約 2 カ月でほとん ぞ分解して塗膜の形を止めないこと，その劣化の機構と 乙て第一の特徴はメチレン鎖の消失であり，第二はカル ボニル基・水酸基などの酸化基の生成であること，また 物性的には光沢を失い，硬くるろくなってきてついに八 ク離したり，溶失したりすることを確かめた。

著者らが先に合成したウレタン化油は，先の塗膜が非 常に強じんで，耐摩耗性・光沢气の他もすぐれて拉り有 望な塗膜形成材であるが2)，これらの点関して，Robinson がその性能を伝壳 ${ }^{3)}$, Pansing(), Stanton ${ }^{5)}$, Too$\mathrm{ne}^{6)}$ の解説などもめる。著者らもその塗膜の屋内放置の

\footnotetext{
昭 41. 6. 6 受理

* 第 3 報本誌 39 [4]189 196 (1966)

** 鹿児島大学工学部 鹿児島市鴨池町 52

*** 埼玉大学理工学部 浦和市常盤町

***** 大島実業高校笠利分校 鹿児島県大島郡笠利町
}

際の黄変については研究した778)。屋外基露試験は前記 Robinson $^{3)}$ が報じているが，暴露の際の赤外スペクトル 測定は行なわれず，劣化の機構は知られていない。そこ で筆者らは合成した各種ウレタン化油の塗膜を暴露して， その赤外スペクトル変化を追及し, また物性変化を研究 した。

\section{2. 研 究 方 法}

\section{1 試料}

4 種のウレタン化油を合成して使用したが，合成用の 原料は下記のものを用いた。トール油脂肪酸は市販の蒸 留品を使用し, 異性化トール油脂肪酸は, トール油脂肪 酸を Bradley のエチレングリコールを溶剤とするアル

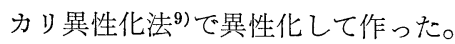

米ヌカ油脂肪酸は米ヌカ油からアルカリケン化による 常法で作った。これら脂肪酸の性状を表-1 に示す。 ペンタエリトリット（以下 $\mathrm{PE}$ と称す一融点 $242 \sim 243$

表-1 原料脂肪酸の性状

\begin{tabular}{c|c|c}
\hline 脂 肪 酸 & 中和価 & $\begin{array}{c}\text { ヨウ素価 } \\
\text { (ウイス法) }\end{array}$ \\
\hline トール 油脂肪酸 & 191.9 & 141.6 \\
異性化トール油脂肪酸 & 191.8 & 123.5 \\
米 カ 油脂肪 酸 & 195.2 & 112.3 \\
\hline
\end{tabular}


表-2 セミェステル

\begin{tabular}{|c|c|c|c|c|c|c|}
\hline 番 & & 肪 & 酸 & $\begin{array}{l}\mathrm{PE} \text { 対脂肪 } \\
\text { 酸 モル比 }\end{array}$ & 酸価 & $\begin{array}{l}\text { ヒドロキ } \\
\text { シル 佂 }\end{array}$ \\
\hline 1 & \multicolumn{3}{|c|}{ トール油脂肪酸 } & $1: 3$ & 2.2 & 91.1 \\
\hline 2 & \multicolumn{3}{|c|}{ トール油脂肪酸 } & $1: 2$ & 3.2 & 160.2 \\
\hline 3 & \multicolumn{3}{|c|}{ 異性化卜ール油脂肪酸 } & $1: 3$ & 1. 2 & 93.1 \\
\hline 4 & \multicolumn{3}{|c|}{ 米ヌカ油脂肪酸 } & $1: 2$ & 2.8 & 132.6 \\
\hline
\end{tabular}

${ }^{\circ} \mathrm{C}$, 水酸基 $49.7 \%$ ) を表-1 の脂肪酸で表-2 記載の割 合で部分的にエステル化してセミエステルとし，残存す る水酸基をトリレンジイソシアネート（以下 TDI と称 す。 $2.4-/ 2.6-=80 / 20$ の市販品）と反応させてウレタ ン化油を製造した。

エステル化法は表-2 の割合の脂肪酸と $\mathrm{PE}$ 混合物計 約 $200 \mathrm{~g}$ を, $500 \mathrm{cc}$ 四つロフラスコに採り, 表面に窒素 を送りながら，油浴に浸し激しくかきまぜながら，200 ${ }^{\circ} \mathrm{C}$ で 2 時間, $230^{\circ} \mathrm{C}$ で 4 時間反応させて作った。生成七 ミエステルは表 -2 の酸価・ヒドロキシル価を示した。こ のセミエステルを当量の TDI と反応させてウレタン化 油を製造したが，方法は先に合成した方法2゙によった。 すなわちセミエステルに対し $\mathrm{Pb}$ 叔よび Co のナフテネ ートの石油ベンジン溶液を，Pb 0.4\%，Co 0.05\%にな るように加它, 三つロフラスコ中で当量の TDI と, 60 ${ }^{\circ} \mathrm{C} 30$ 分, $70^{\circ} \mathrm{C} 30$ 分, $80^{\circ} \mathrm{C} 30$ 分反応させ, 逐次キシレ ンを加え, キシンン $50 \%$ 溶液の形でウレタン化油を製 造した。矢の性状を表-3 に示す。

表-3 ウレタン化油（キシレン $50 \%$ 溶液）

\begin{tabular}{c|cc|c|c}
\hline 番 & 名 & 称 & 酸価 & $\begin{array}{c}\text { 粘 } \\
\text { ポイズ } \\
25^{\circ} \mathrm{C}\end{array}$ \\
\hline 1 & トールペンタ $3: 1$ ウレタン & 0.54 & 0.28 \\
2 & トールペンタ $2: 1$ ウレタン & 0.62 & 0.94 \\
3 & 其トールペンタ $3: 1$ ウレタン & 0.41 & 0.54 \\
4 & 米ヌカペンタ $2: 1$ ウレタン & 0.70 & 0.77 \\
\hline
\end{tabular}

\section{2 暴露塗膜赤外スペクトルの測定法}

前報の方法1)で, ポリエチレンフィルム $(20 \mu)$ 上に,
2 ミルのドクターブレードで塗装し, 室内に 1 週間放置 後, 塩ビの枠に入れて 1964 年 8 月 28 日から, 鹿児島 市鴨池町の鹿児島大学工学部応用化学科 3 階建物の屋上 に, 南面 $30^{\circ}$ で暴露し塗膜の暴露前（塗布後 1 週間）打 よび暴露後破壊するまでの間, 適当な間隔で, 塗装して いないポリエチンンフィルムを補償光路に入れて, 日本 分光 301 型赤外分光光度計 $(\mathrm{NaCl}$ プリズム) で, 赤外 スペクトルを測定した。暴露時 10 カ月間の気象状況を 表-4 に示す。

\section{3 暴露塗膜の物性・重量変化測定法}

やはり前報と同じ方法1)で, $8 \times 11 \times 0.2 \mathrm{~cm}$ のガラス 板执よび $5 \times 15 \times 0.03 \mathrm{~cm}$ のブリキ板に 2 ミル (幅 $5 \mathrm{~cm})$ のドクターブレードで塗装し 1 週間室内に放置した塗膜 を, 赤外スペクトルの場合と同じ場所で暴露試験し，塗 膜の破壊するまで, ガラス板塗膜について重量・光沢 （東芝製 CGS 3 型色沢計， $45^{\circ}$ 反射率一ガラス板を 100 として測定), 硬度 (スオードロッカー), ブリキ板塗膜 について $2 \mathrm{~mm}$ 心棒屈曲試験(キレッの入った角度を読 む。 $180^{\circ}$ 曲げてもキレッの入らなかったものは pass)を 行なった。別にガラス板に塗装した塗膜について， $23^{\circ} \mathrm{C}$ ・50\% 湿度の室内での指触, 硬化乾燥時間を測定した。

\section{3. 結 果}

\section{1 赤外スペクトル変化}

トールペンタ $3: 1$ ウレタンの赤外線吸収スペクトル を図-1 に示す。塗膜は10 カ月でキレッを生じ, 八ク離 したのでそれまでで中止した。1月フィルムと書いたの は 1 カ月暴露後の塗膜のスペクトルであり, 以下同様に 記した。塗膜は硬くホコリ（細塵）はほとんぞ付着しな かったが，時により多少ベースラインは異なっていた。

つぎにトールペンタ $2: 1$ ウレタン塗膜のスペクトル 変化を図-2に示すが，この場合は 6 カ月までで塗膜がキ レッを生じてハク離したので, そこまでで実験を止めた。 異トールペンタ $3: 1$ ウレタン塗膜も 10 カ月まで破壊 しなかった。そのスペクトル変化を図-3 に示す。

表-4 気 象条件

\begin{tabular}{|c|c|c|c|c|c|c|c|c|c|c|}
\hline & 39 年 9 月 & " 10月 & "I 11月 & II 12 月 & 40 年 1 月 & "I 2 月 & " 3 月 & " 4 月 & " 5 月 & " 6 月 \\
\hline (最 高 & 34.1 & 30.0 & 27.1 & 20.7 & 17.4 & 18.9 & 19.6 & 25.1 & 29.7 & 29.5 \\
\hline 気温 ${ }^{\circ} \mathrm{C}\{$ 最 低 & 14.4 & 8.7 & 2.0 & -1.0 & -1.8 & -4.0 & -2.0 & 2.2 & 8. 6 & 14.4 \\
\hline 平 均 & 25.8 & 20.9 & 13.3 & 9.3 & 6.6 & 8. 2 & 9.2 & 14.8 & 19.5 & 22.3 \\
\hline 平均相対湿度 $\%$ & 78 & 73 & 73 & 73 & 73 & 69 & 65 & 72 & 76 & 84 \\
\hline 降水量 $\mathrm{mm}$ & 184.1 & 177.6 & 62.4 & 55.1 & 53.6 & 64.4 & 60.0 & 274.6 & 277.4 & 342.1 \\
\hline 日 照 率 $\%$ & 52 & 54 & 72 & 47 & 47 & 44 & 55 & 44 & 38 & 22 \\
\hline
\end{tabular}




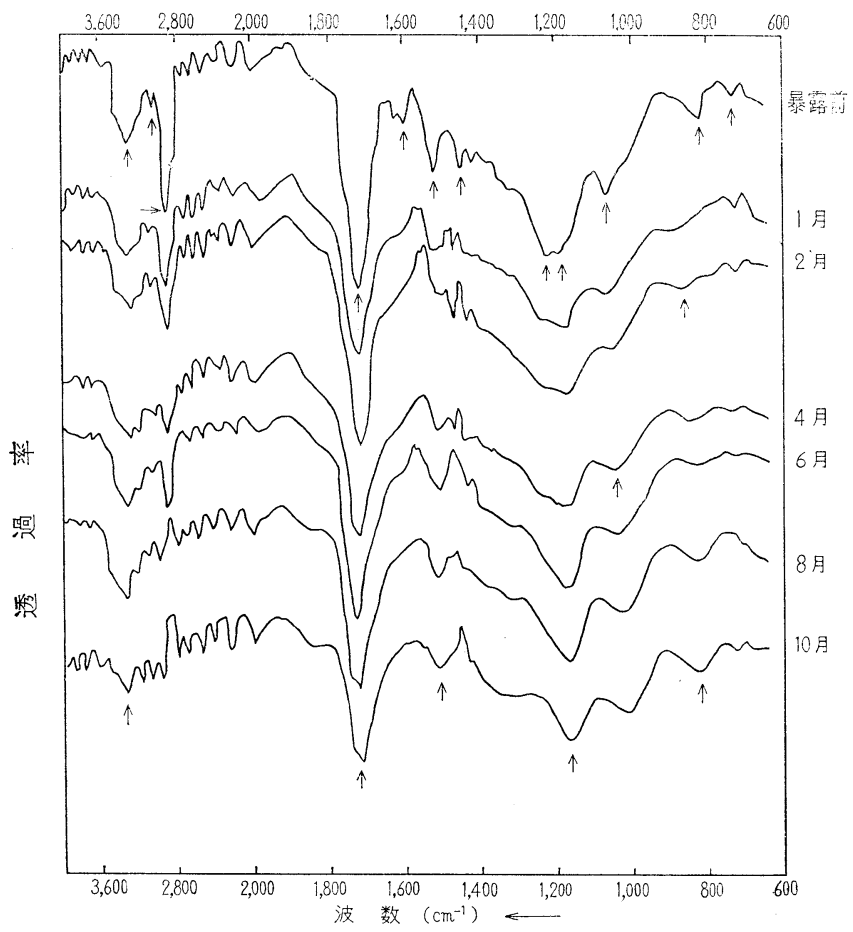

図-1 トールペンタ $3: 1$ ウレタン塗膜の赤外スペクトル

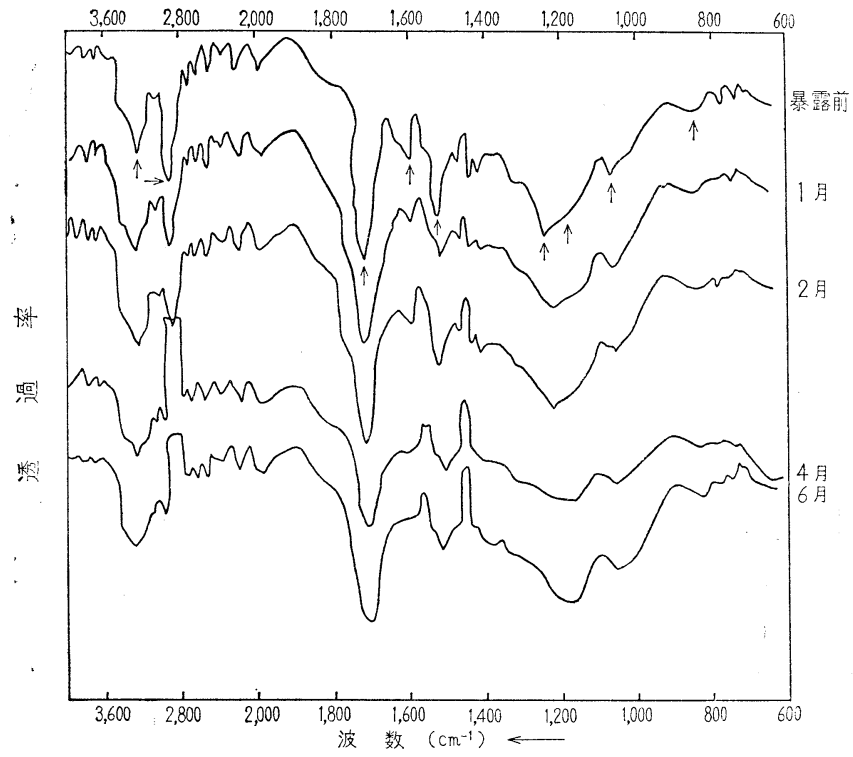

図-2トールペンタ 2:1 ウレタン塗膜の赤外スペクトル
米ヌカペンタ $2: 1$ ウレタン塗膜もやっと 10カ月をで耐觉た。そのスペクトル変化を図 -4 に示す。

\section{2 乾燥時間}

各試料の乾燥時間を表-5 に示す。 表-5 乾 燥 時 間

\begin{tabular}{cc|r|r}
\hline 試 & \multicolumn{1}{c|}{ 料 } & $\begin{array}{c}\text { 指触 } \\
(\mathrm{min})\end{array}$ & $\begin{array}{c}\text { 硬华 } \\
(\mathrm{min})\end{array}$ \\
\hline トールペンタ $3: 1$ ウレタン & 60 & 110 \\
トールペンタ & $2: 1$ ウレタン & 13 & 22 \\
異トールペンタ 3:1 ウレタン & 14 & 25 \\
米ヌカペンタ $2: 1$ ウレタン & 14 & 45 \\
\hline
\end{tabular}

\section{3 重量変化}

\section{塗膜の重量変化を図-5 に示す。}

測定は塗膜にキレッを生ずるかあるいはハ ク離するまで継続した。1のトールペンタ3:1 ウレタンが一番長く 6 カ月測定できた。同じ ブレードで塗装したのであるが，塗り終った 部分が多少厚くなったりして 4 は塗膜が少し 厚かった。塗膜の重量減少は崩填による溶解 または揮散によるものである。

3.4 硬度変化

硬度 (スオードロッカー) 変化を図-6に示 于。

アマニ油・重合シナキリ油の場合にも観察 されたように 硬度は増加する傾向がある。はじめ硬度の低 かった塗膜が暴露によっての硬度上昇が大き く、はじめから硬かったものはあまり変化し ないが，いずれも破壊する前には硬度 20 以 上に到達している。

3.5 光沢変化

光沢の変化を図-7 に示す。

前報1) の乾性油が 1 カ月で $20 \%$ 台に落ち たのに比べると，りレタン化油の光沢は非常 によい。大体 1 カ月で $60 \%$ 台に落ち以後ま まり変化しない。光沢的にはすぐれている。

\section{6 屈曲試験}

屈曲試験はブリキ板の都合で 3 カ月に 1 回 行なった。結果を表-6 に示す。

この方は塗膜がいずれも 6 カ月まで残存し たが，1と 4 がすぐれていた。アルカリ異性 化油を除けば, 脂肪酸側のヨウ素価が大きな トール油脂肪酸の場合は $3: 1$ ウレタンの方 


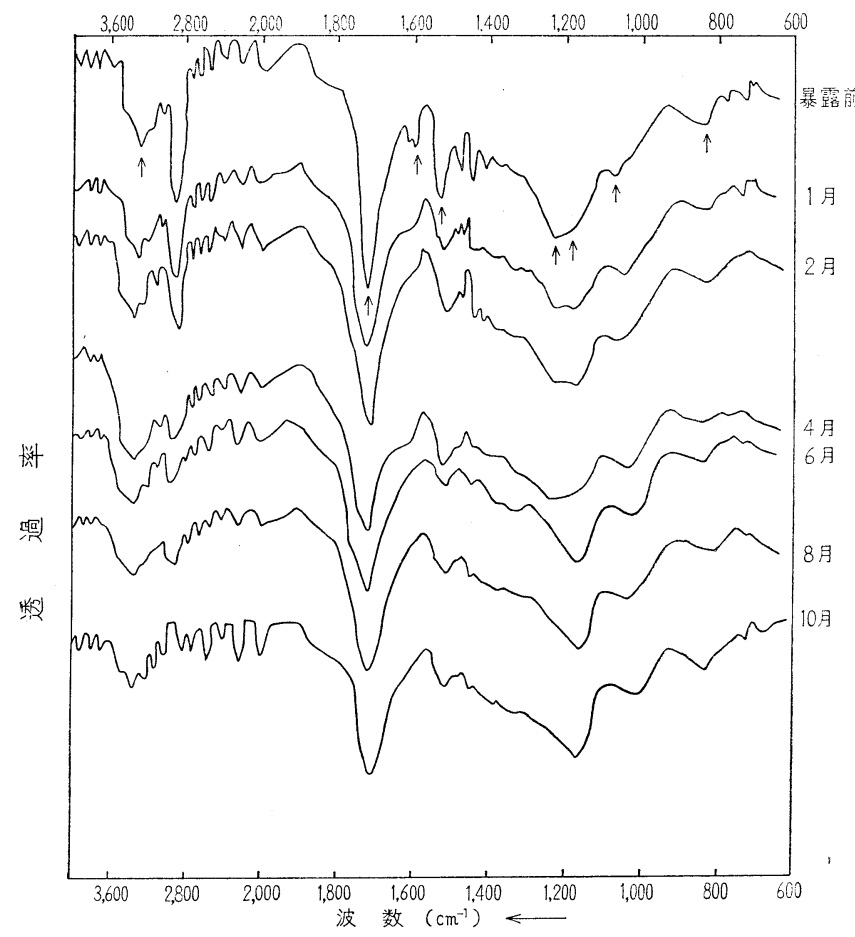

図-3 異トールペンタ $3: 1$ ウレタン叙膜の赤外スペクトル

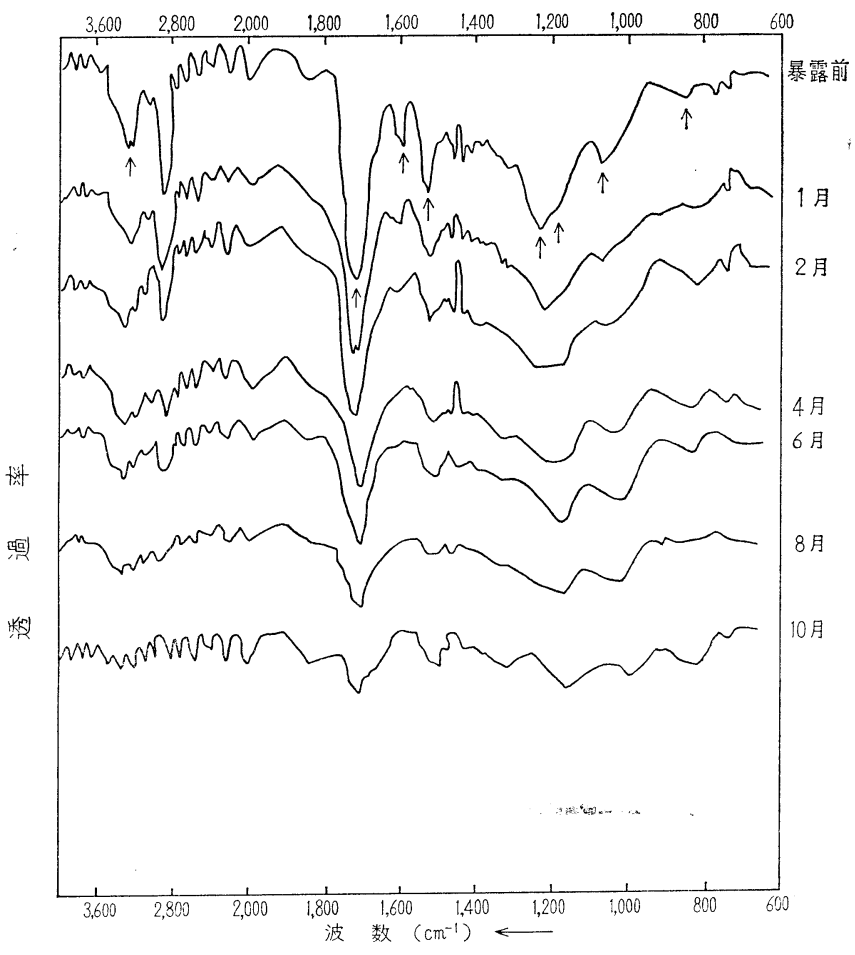

図-4 米ヌカペンタ $2: 1$ ウレタン塗膜の赤外スペクトル

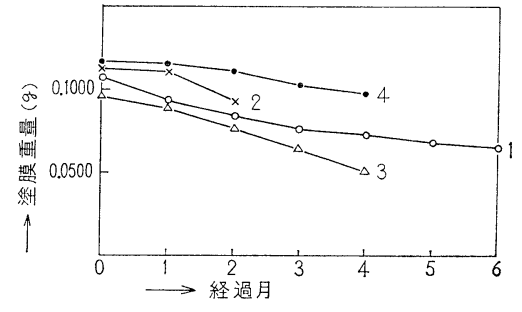

図-5 重 量 变 化

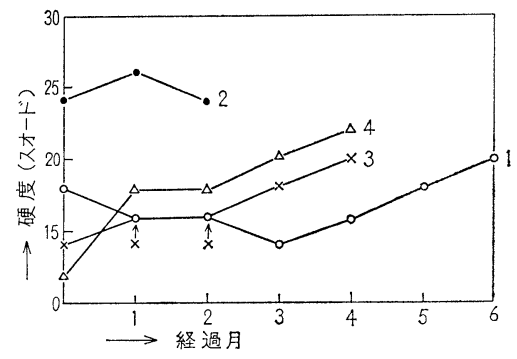

図-6 硬 度 变 化

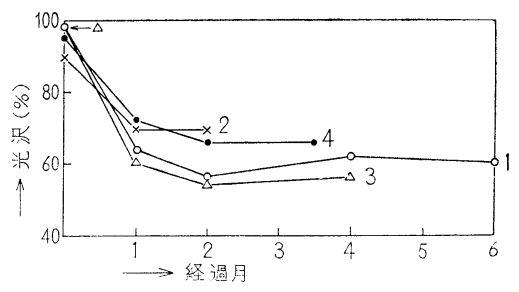

図-7 光 沢 変 化

表-6 屈 曲試 験

\begin{tabular}{|c|c|c|c|c|}
\hline 番号 & 料 & 暴露前 & 3 月 & 6 月 \\
\hline 1 & $\begin{array}{l}\text { トールペンタ } \\
3: 1 \text { ウレタン }\end{array}$ & pass & pass & \\
\hline 2 & $\begin{array}{l}\text { トールペンタ } \\
2: 1 \text { ウレタン }\end{array}$ & pass & pass & $\begin{array}{l}90^{\circ} \\
\text { キレッ }\end{array}$ \\
\hline 3 & $\begin{array}{l}\text { 異トールペンタ } \\
3: 1 \text { ウレタン }\end{array}$ & pass & pass & $\begin{array}{l}135^{\circ} \\
\text { ハク離 }\end{array}$ \\
\hline 4 & $\begin{array}{l}\text { 米ヌカペンタ } \\
2: 1 \text { ウレタン }\end{array}$ & pass & pass & pass \\
\hline
\end{tabular}

が, $2: 1$ ウレタンより屈曲性の変化が少な く, 脆化乙難い。

\section{4. 考察}

以上の結果について, 各ウレタン化油の赤 外スペクトル変化と物性変化とについて考察 する。 


\section{1 トール油ペンタ 3:1 ウレタン}

図-1 の 8 月フィルム, 10 月フィルムの $2926 \mathrm{~cm}^{-1}$, $1460 \mathrm{~cm}^{-1}$ 吸収をみてわかるよ5に，この試験に用いた ポリエチレンフィルムは, 補償光路に用いたポリエチレ ンフィルムより薄い。すなわち前報の（C）型である。 したがって $2926 \mathrm{~cm}^{-1}, 1460 \mathrm{~cm}^{-1}$ 吸収の減少速度は塗膜 が薄くなる速度より速い。この点を注意しなければなら ない。さて図-1 の暴露前フィルムの主な吸収について, その帰属を調べてみると表-7 のようになる。

表-7トールペンタ $3: 1$ ウレタン吸収

\begin{tabular}{|c|c|c|c|}
\hline $\begin{array}{l}\text { 吸收 } \\
\text { 波数 } \\
\mathrm{cm}^{-1}\end{array}$ & 結 & 吸収種 類 & $\begin{array}{l}\text { 引用 } \\
\text { 文献 }\end{array}$ \\
\hline 3460 & 遊離 $\mathrm{N}-\mathrm{H}$ & 伸縮振動 & 10 \\
\hline 3300 & 会合 $\mathrm{N}-\mathrm{H}$ 抢よび O-H & 伸縮振動 & 10 \\
\hline 3060 & ベンゼン核 C-H & 伸縮振動 & 11 \\
\hline 2926 & $-\mathrm{CH}_{2-}$ & 逆対称伸縮振動 & 13 \\
\hline 1725 & $\begin{array}{l}\text { アミド } \mathrm{I}, \text { ウレタン } \mathrm{C}=\mathrm{O} \\
\text { 物よびエステル } \mathrm{C}=\mathrm{O}\end{array}$ & 伸綝 & 12,13 \\
\hline 1600 & ベンゼン核 & 伸縮振動 & 11 \\
\hline 1525 & アミドII & & 11 \\
\hline 1230 & $\begin{array}{l}\text { アミドIII +エステル } \\
\mathrm{C}-\mathrm{O}-\mathrm{C}\end{array}$ & $\begin{array}{l}\text { エステル } \\
\text { 伸縮振動 }\end{array}$ & 11 \\
\hline 1175 & エステル C-O-C & 伸縮振動 & 13,1 \\
\hline 1065 & カルバメート C-O-C & 伸縮振動 & 14 \\
\hline 1035 & ペンタェリトリット & 骨 格 & 15 \\
\hline 815 & 1,2,4 三置換ベンゼン & 面外変角振動 & 13 \\
\hline 770 & 1,2,3 三置換ベンゼン & 面外变角振動 & 13 \\
\hline 730 & $-\mathrm{CH}_{2}-$ & 横ゆれ振動 & 13 \\
\hline
\end{tabular}

暴露前フィルムのこれら吸収は暴露の経過とともにい ろいろな変化をし，また暴露 1 月からエポキシ基による と思われる ${ }^{15)} 845 \mathrm{~cm}^{-1}$ 吸収を生じ，4月フィルムから は $1065 \mathrm{~cm}^{-1}$ の吸収は $1050 \mathrm{~cm}^{-1}$ から $1030 \mathrm{~m}^{-1}$ に極大 を有するなだらかな吸収に変化する。これは前報の乾性 油塗膜の劣化の場合も現われた現象で1), $3300 \mathrm{~cm}^{-1}$ 吸収 増大とも市わせ考㝋てアルコール水酸基を中心とする吸 収であると考觉られる。

これら吸収の消長は吸収の重なり合いのために正確に 知ることはできない。たとえば $1230 \mathrm{~cm}^{-1}$ 吸収と 1175 $\mathrm{cm}^{-1}$ 吸収は一部重なり合い, $1065 \mathrm{~cm}^{-1}, 1035 \mathrm{~cm}^{-1}$ の またりはいろいろな吸収が重なって出てきている。しか しこの点を注意すれば, 大体ラジカルの消長を吸収変化 から追及することができる。各吸収の補正ベースライン による吸光度を調べ暴露前フィルムのそれを $100 \%$ とし て図に描けば図-8，図-9 のようになった。

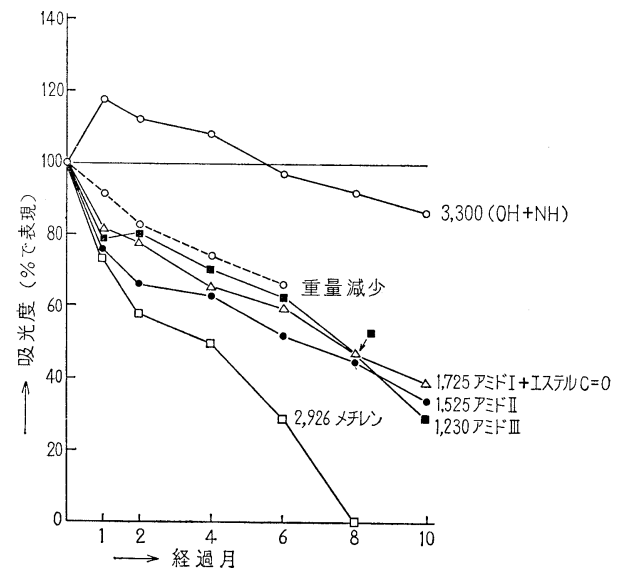

図-8 各吸収の変化 I（トールペンタ $3: 1$ ウレタン）

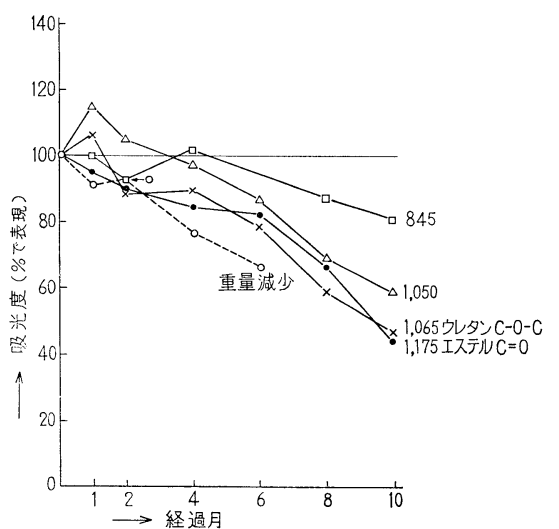

図-9 各吸収の变化 $I$ （トールペンタ $3: 1$ ウレタン）

図には先に示したガラス板塗膜で測定した重量変化を も点線で示した。スペクトル測定の場合にも大体に招い て点線に沿った重量減少が現われているとみてよいので, この点線と同傾向の減少を示した波数の吸収は, その原 子団が単位重量塗膜中で, 扮扣を社增減を見せなかった と考觉てよい。このグループに属するものに, $1725 \mathrm{~cm}^{-1}$, $1525 \mathrm{~cm}^{-1}, 1230 \mathrm{~cm}^{-1}$ のアミドI, II, III吸収が入り, ウレタン結合部は塗膜暴露の際変化を受けないといらこ とがいえる。その吸収減少が直線的にならないのは暴露 の時期の影響であり，8 月 28 日に暴露開始したので, はじめの 1 月間に激しく劣化したためである。

$1065 \mathrm{~cm}^{-1}$ のカルバメート C-O-C 吸収は, 和そらく $1050 \mathrm{~cm}^{-1}$ 吸収の影響でこれらアミド吸収より減少が少 ない。増加傾向を示しているのは $3300 \mathrm{~cm}^{-1}$ の $\mathrm{OH}+\mathrm{NH}$ 吸取で女り， $\mathrm{NH}$ の増加はないからこれは主として $\mathrm{OH}$ 
基の増加によるものと思われるが， $\mathrm{OOH}$ 基の吸収も分 離し難いので入っているのかも知れない。 $845 \mathrm{~cm}^{-1}$ の工 ポキシ吸収もかなり増加している。これより少いが 1050 $\mathrm{cm}^{-1}$ 吸收（アルコール OH を主とする）, $1175 \mathrm{~cm}^{-1}$ の エステル吸収も増加傾向を示している。

すなわら劣化の特徵として，アルコール，エポキシ， エステルなど各種含酸素基の増加があげられる。

一方 $2926 \mathrm{~cm}^{-1}$ のメチレン基は塗膜重量減少よりも著 しく速い速度で減少する。前述のよ5にこの減少には塗 布ベースのポリエチレンフィルムが補償用フィルムより 薄かった影響もあるが，その差は 10\% 以下であったの でたとえば 6 月フィルムに执いてガラス板の場合には 塗膜重量が，暴露前重量の約 $60 \%$ 女るのに（図-5 参 照), $2926 \mathrm{~cm}^{-1}$ 吸光度が $24 \%$ しか示さないのは, 明ら かに塗膜中のメチレン部の消失を意味している。これは 前報1)でも著しく現われた現象であり，酸化・重合・分 解の反応がメチレン部で起こり激しく減少するものと思 万。

前報で著しかったケトンカルボニルの増加は，今度は 余り激しくなく， $1725 \mathrm{~cm}^{-1}$ 吸収が幾分低波数側に広が りを見せたが，極大は最後まで $1725 \mathrm{~cm}^{-1}$ にあり，この ケトン増加の少ないことが，普通の乾性油より，ウレタ ン化油が耐久力のよい一つの原因になっていると推定し た。

\section{2 トールペンタ 2:1 ウレタン}

図-2 のトールペンタ 2:1 ウレタンの赤外吸収拈よび その変化は，大体に招いて図-1に一致しているが，その 吸収強度に違いがある。 4 種のウレタン化油暴露前フィ ルムの $2926 \mathrm{~cm}^{-1}$ メチレン吸収に対する各吸収の吸光度 比\%を表-8 に示す。

表-8 でわかるようにトールペンタ $2: 1$ ウレタンは， $3300 \mathrm{~cm}^{-1}$ の $\mathrm{OH}+\mathrm{NH}, 1600 \mathrm{~cm}^{-1}$ のベンゼン核, 1525 $\mathrm{cm}^{-1}$ のアミド亚吸収などが，トールペンタ $3: 1$ ウレ
タンより大きく，ウレタン含量の多いことを示してい る。 $1725 \mathrm{~cm}^{-1}$ 吸収が小さい理由は，アミドIのカルボ ニル十エステルカルボニルは $2: 1$ ウレタンの方が少な いからであろう。この場合も各吸収の消長は大体 $3: 1$ ウレタンの場合と似ているが， 6 カ月で $2926 \mathrm{~cm}^{-1}$ のメ チレンの消失が著しかった。これはメチレンの酸化・重 合が非常に速く進行したことを示しており，これが表-6 の屈曲試験での可とう性の低下という現象を呼び起こし ている。6 カ月を経過した後遂にこの塗膜はキレッを生 じてハク離してしまった。トールペンタ $2: 1$ ウレタン柋, 耐水性その他の性質が 3:1 ウレタンよりすぐれていた のでめるが2), 屋外暴露試験では， $3: 1$ ウレタンの方が 良いことがわかった。屋外用の塗料には，トール油脂肪 酸のようにかなりヨウ素価の高い脂肪酸を用いたウレタ ン化油では, ウレタン含量が多くなく柔軟性のある塗料 の方が良い。

\section{3 異トールペンタ 3:1 ウレタン}

アルカリ異性化脂肪酸の多価アルコールエステルは一 般にその塗膜性状がすぐれていたので16)，異性化トール 油脂肪酸のウレタン化油をつくって試験してみた。

その赤外スペクトル図（図-3），表-8 を見てわかるよ うに，暴露前フィルムはトールペンタ $3: 1$ ウレタンの 場合とその吸収位置, 吸光度関係がほとんぞ一致し，元 の暴露スペクトルも差はなく，耐候性は同程度のもので あることがわかった。しかしガラス板塗膜は 4 カ月まて しかもたず，幾分異性化しないものの方がよい。

\section{4 米ヌカペンタ 2:1 ウレタン}

この場合も，他のウレタン化油の場合と吸収波数は同 じであり，各吸収の $2926 \mathrm{~cm}^{-1}$ 吸収に対する吸光度比心 $3300 \mathrm{~cm}^{-1}$ の $\mathrm{OH}, \mathrm{NH}$ 吸収が小さいほかは, トールペ ンタ $2: 1$ ウレタンと大体一致している。

米ヌカ油脂肪酸は， ヨウ素価がトール油脂肪酸より小 さいので，それだけ Hydroperoxide や水酸基の生成ぶ

表-8 各吸収 の吸光度比

\begin{tabular}{|c|c|c|c|c|c|}
\hline \multirow{2}{*}{$\begin{array}{c}\text { 吸 収 } \\
\text { 波数 } \\
\mathrm{cm}^{-1}\end{array}$} & & \multicolumn{4}{|c|}{$2926 \mathrm{~cm}^{-1}$ 吸収に対する吸光度（\%) } \\
\hline & 結 & $\begin{array}{l}\text { トールペンタ } \\
3: 1 \text { ウレタン }\end{array}$ & $\begin{array}{l}\text { トールペンタ } \\
2: 1 \text { ウレタン }\end{array}$ & 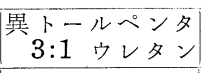 & $\begin{array}{l}\text { 米ヌカペンタ } \\
2: 1 \text { ウレタン }\end{array}$ \\
\hline 3300 & $\mathrm{OH}+\mathrm{NH}$ & 44 & 70 & 47 & 54 \\
\hline 1725 & アミド $\mathrm{I}+$ ステル $\mathrm{C}=0$ & 257 & 237 & 247 & 241 \\
\hline 1600 & ベンゼン核 & 31 & 65 & 48 & 57 \\
\hline 1525 & ア ミ ド III & 65 & 126 & 84 & 122 \\
\hline 1230 & アミドIII+エステル C-O-C & 143 & 165 & 144 & 153 \\
\hline 1175 & エステル C-O-C & 132 & 133 & 128 & 127 \\
\hline 1060 & カルバメート C-O-C & 79 & 94 & 74 & 81 \\
\hline 815 & 1,2,4 三置換ベンゼン & 30 & 34 & 34 & 29 \\
\hline
\end{tabular}


少ないと思われる。この $2: 1$ ウレタンは, しかしトー ル油ペンタ $2: 1$ ウレタンより, ほじめの塗膜の硬度な どは劣っているが，かえって耐候性はよく, 10 カ月間キ レッを生ぜずに塗膜が残存した。すなわち脂肪酸ペンタ エリトリット 2:1 のウレタン化油を作るときは, 米ヌ カ油のような半乾性油脂肪酸の方がすぐれている。

\section{5 物性変化との総合考察}

以上ウレタン化油の赤外線吸収スペクトル変化を中心 にして, 屋外暴露の際の劣化の構造変化を考察してきた のであるが, 赤外スペクトル测定のフィルムでは, トー ルペンタ $2: 1$ ウレタンが 6 カ月でハク離したのに対し， 他は 10 力月暴露に耐光た。また物性測定のガラス板塗 膜では, トールペンタ $3: 1$ ウレタンが 6 カ月耐党, 異 トールペンタ $3: 1$ ウレタンと米ヌカペンタ $2: 1$ ウレ タンが 4 カ月, トールペンタ $2: 1$ ウレタンが 2 カ月ま で耐えた。これらの事実から判断すれば，4種のウレタ ン化油の5ちではトールペンタ $3: 1$ ウレタンが一番塗 膜耐久力がよく, ついで異トールペンタ $3: 1$ ウレタン, 米ヌカペンタ $2: 1$ ウレタンがよく, トールペンタ $2: 1$ ウレタンが一番劣る。

しかし前報のアマニ油, 重合シナキリ油塗膜と比べる そ，いずれも格段にすぐれて扣り，これら塗膜が顔料を 含まないために，紫外線の影響を内部まで受けること， 膜厚が 1 ミル程度であること, ガラス板, ポリエチレン フィルムなどへの塗装であることなど, 悪い条件下で実 験した割にはすぐれた酎候性を持っているといえる。顔 料を含まないのではっきりとはわかりにくかったが，塗 膜の黄変は大して目立たなかった。光沢低下も乾性油が 1 カ月で $20 \%$ 以下に落ちるのと比べれば，60\% 程度に 落ちるだけで低下が小さい。また劣化に伴う硬度変化も 小さくトールペンタ $3: 1$ ウレタン, 米ヌカペンタ $2: 1$ ウレタンでは 6 カ月フィルムでも $2 \mathrm{~mm}$ 心棒で $180^{\circ}$ の 屈曲渜える。以上いろいるな点から考察して, ウレタ ン化油は屋外塗装用塗料に使用しても, 十分耐候性のあ
ることがわかった。その劣化機構としては，ウレタン結 合には変化なく, 水酸基・エポキシ基・エステル基など の含酸素基の増加と，それに伴うメチレン部の減少が主 因であり,さらに重合・分解が起こって塗膜が劣化して いくものと推定した。

最後に試料を戴いた播磨化成工業株式会社, 広栄化学 工業株式会社に厚く謝意を表する。

この内容は昭和 40 年 12 月 3 日, 日本化学会九州・ 中国・四国合同常会で講演した。

また研究費の一部は, 昭和 39 年度文部省科学試験研 究費によった。

$$
\text { 文献 }
$$

1) 竹下, 宮内, 今扶, 色材, 39, 189 (1966).

2) 竹下, 宮内, 今井, 色材, 37, 381 (1964).

3) E. B. Robinson, R. B. Waters, J. Oil and Colour Chemist's Assoc., 34, 361 (1951).

4) H. E. Pansing, Official Digest, 30, 37 (1958).

5) J. M. Stanton, J.Am. Oil Chemists'Soc., 36, 503, (1959).

6) G. C. Toone, Dyestuffs, 44 (1), 7 (1961).

7) 竹下, 宮内, 今井, 中川, 岩重, 色材, 38, 172 (1965).

8) 竹下, 宮内, 今井, 色材, 38, 473 (1965).

9) T.F. Bradley, Ind. Eng. Chem., 34, 237 (1942).

10) A. Weissberger, Technique of Organic Chemistry, Vol. X Interscience Publishers, Inc., New York (1956) p. 510, 516

11） A. D. Cross, 名取, 千原, 赤外線吸収スペクトル 入門，東京化学同人 (1960) p. 79 .

12）島内他, 赤外線吸収スペクトル第 11 集, 南江堂 (1960) p. 106.

13）中西, 赤外線吸収スペクトル, 南江堂 (1960) p. $49,32,26$.

14) H. C. Beachell, C. P. Ngocson, J. Applied Polymer Sci., 7, 2217 (1963).

15) C. R. Bragdon, Film Formation, Film Properties and Film Deterioration, Interscience Pulishers, Inc., New York (1958) p. 130.

16) 竹下, 工化, 63, 579 (1960). 